\title{
Pemberdayaan Ibu Rumah Tangga dalam Mengelola Sampah di Lingkungan II Kelurahan Asam Kumbang, Medan
}

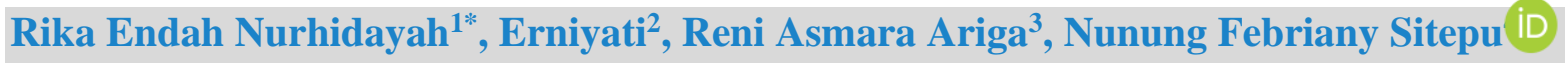 \\ ${ }^{1,2,3,4}$ Fakultas Keperawatan, Universitas Sumatera Utara, Indonesia \\ *Corresponding author: rika_endah@usu.ac.id
}

\begin{abstract}
Kerusakan lingkungan salah satunya disebabkan oleh pencemaran lingkungan karena penumpukan sampah yang sampah yang sulit untuk diurai kembali (anorganik). Contoh sampah anorganik yang membutuhkan waktu puluhan tahun untuk dapat terurai adalah adalah plastik. Program kegiatan pengabdian masyarakat ini bertujuan untuk memberdayakan ibu-ibu rumah tangga di Lingkungan II Kelurahan Asam Kumbang Medan agar mau berpartisipasi untuk mengelola sampah menjadi kerajinan tangan yang bernilai ekonomis. Selama ini ibu-ibu sudah aktif terlibat dalam pengumpulan sampah plastik kemasan, namun melalui pemberdayaan ini, diharapkan ibu-ibu bukan hanya berpatisipasi dalam pengumpulan sampahnya tetapi juga diharapkan dapat berpartisipasi dalam pembuatan kerajinannya. Produk yang dihasilkan sangat beragam, selain untuk dipakai sendiri, hasilnya juga dapat dijual yang tentunya memberi nilai ekonomis dan dapat menjadi tambahan penghasilan buat keluarga.
\end{abstract}

Keywords: Sampah Plastik, Kerajinan Tangan, Bernilai Ekonomis

\section{Abstract}

One of the causes of environmental damage is environmental pollution due to the accumulation of garbage which is difficult to decompose (inorganic). An example of inorganic waste that takes decades to decompose is plastik. This community service program aims to empower housewives in Neighborhood II of Asam Kumbang Village, Medan to participate in managing waste into economically valuable handicrafts. So far, women have been actively involved in collecting plastik packaging waste, but through this empowerment, it is hoped that women will not only participate in collecting their garbage but also participate in making their crafts. The products produced are very diverse, apart from being used alone, the results can also be sold which of course provide economic value and can be an additional income for the family.

Keywords: Plastic Waste, Crafts, Economical Value

\section{Introduction}

Sampah merupakan salah satu masalah yang sering muncul dalam kehidupan di masyarakat. Sampah adalah sisa kegiatan sehari-hari manusia atau proses alam yang berbentuk padat (Dewi et al., 2020; Qorira \& Waskito, 2020). dihadapi tidak hanya di Indonesia saja, tapi di seluruh dunia. Produksi sampah yang terus menerus meningkat seiring dengan pertambahan jumlah penduduk, perubahan pola konsumsi, dan gaya hidup masyarakat (Kahfi, 2017; Wardhani \& Harto, 2018; Yustikarini et al., 2017). Sampah yang kian banyak akan menimbulkan masalah terhadap lingkungan jika tidak ditangani dengan baik (Dewi et al., 2020; Harahap, 2016; Yudistira, 2019). Sampah secara umum dibedakan menjadi dua jenis yaitu jenis organic dan anorganik. Sampah jenis organic adalah sampah yang mudah untuk diuraikan kembali menjadi bagian-bagian yang sederhana misalnya daun, sisa sayuran dan lain sebagainya (Yudistira, 2019). Sedangkan sampah anorganik adalah

$\begin{array}{lll}\text { History: } & & \text { Publisher: Undiksha Press } \\ \text { Received } & \text { : 2 Juni } 2020 & \text { Licensed: This work is licensed under } \\ \text { Revised } & \text { : 1 Juli } 2020 & \text { a Creative Commons Attribution 3.0 License } \\ \text { Accepted } & \text { : 26 Juli } 2020 & \end{array}$


sampah yang sulit diuraikan, dan membutuhkan waktu puluhan tahun untuk terurai misalnya, plastic, belahan kaca dan lain sebagiannya (Marliani, 2015). Jika, masalah ini dibiarkan akan menimbulkan banyak masalah bagi kehidupan manusia.

Salah satu subsistem teknik operasional penanganan sampah adalah melalui pengolahan. Pengolahan merupakan bagian dari kebijakan strategi pengelolaan sampah nasional (Chaerul \& Rahayu, 2019). Prinsip utama pemanfaatan atau pengolahan residu adalah mengubah bahan tersebut menjadi stabil sehingga pada kondisi terpapar di atmosfer tidak berbahaya bagi lingkungan (Naryono, 2011). Berbagai cara dapat dilakukan untuk menanggulangi sampah plastik yang masuk dalam kategori sampah anorganik, Salah satunya adalah dengan memanfaatkan sampah plastik menjadi kreativitas yang bermanfaat serta dapat meningkatkan ekonomi masyarakat (Diana et al., 2018; Nadlifatin, 2018). Sampah bukan saja menjadi berkurang, akan tetapi juga menjadi bernilai ekonomis. Sampah plastik disulap menjadi barang yang berguna kembali, bahkan dapat memiliki nilai jual dan dapat dikreasikan menjadi barang yang memiliki nilai estetika. Hal ini juga sudah dilakukan di beberapa tempat kelurahan, seperti dilakukan oleh keluaran Asam Kumbang.

Masyarakat khususnya ibu-ibu yang berada dilingkunganya 2 kelurahan Asam Kumbang pada dasarnya sudah aktif berpartisipasi dalam mengumpulkan sampah. Ibu Tri dengan dukungan suaminya sebagai kepala lingkungan 2 kelurahan Asam Kumbang, Medan berinisiatif membuat bank sampah. Bank sampah ini pada awalnya bertujuan untuk mendapatkan bahan baku sampah yang dapat dibuat menjadi kerajinan. Awalnya program bank sampah ini juga tidak terlalu mendapat respons positif dari masyarakat, akan tetapi setelah melihat barang-barang sebagai penukar poin-poin yang merupakan kebutuhan sembilan bahan pokok (sembako) dan kebutuhan rumah tangga lainnya seperti gas ukuran 3 $\mathrm{Kg}$, detergen dan lainnya, lambat laun warga mulai tertarik dan memberikan respons yang positif dengan berpartisipasi aktif untuk mengumpulkan sampah plastik kemasan kopi, pewangi pakaian, minuman dan minyak goreng. Hal ini sesuai dengan Gambar 1 dan Gambar 2.
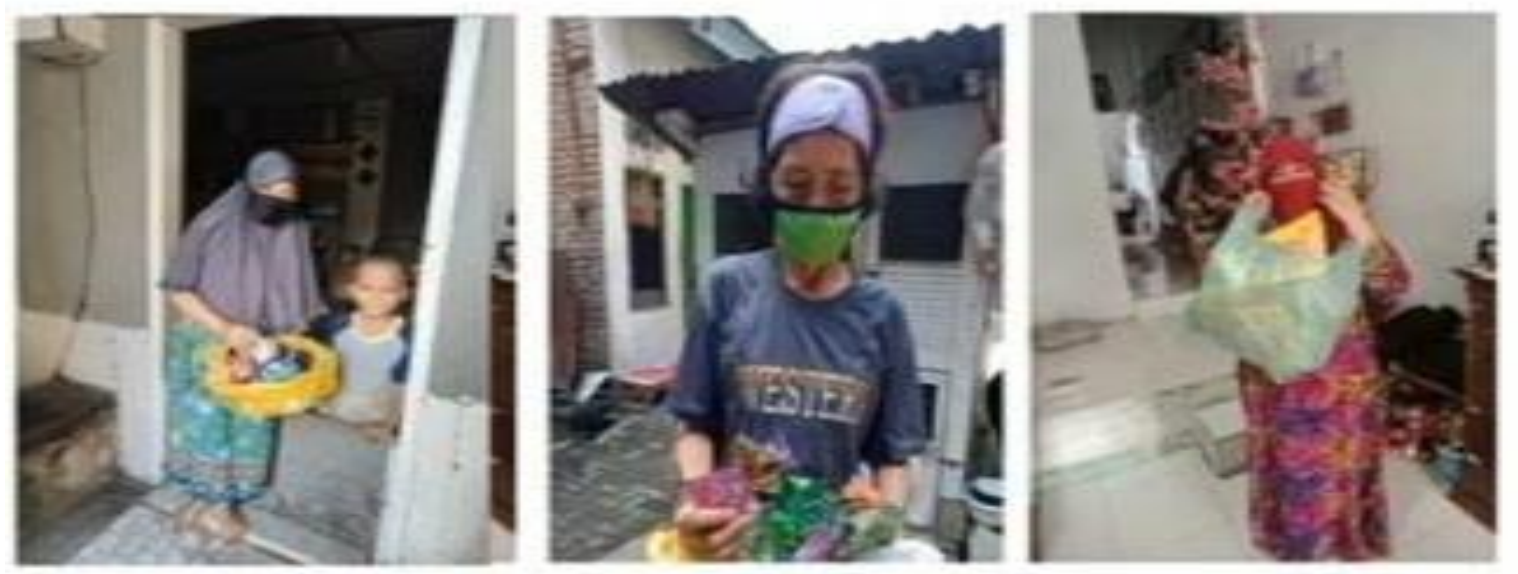

Gambar 1. Partisipasi Warga yang Sudah Berjalan dalam Pengumpulan Sampah ke Bank Sampah 

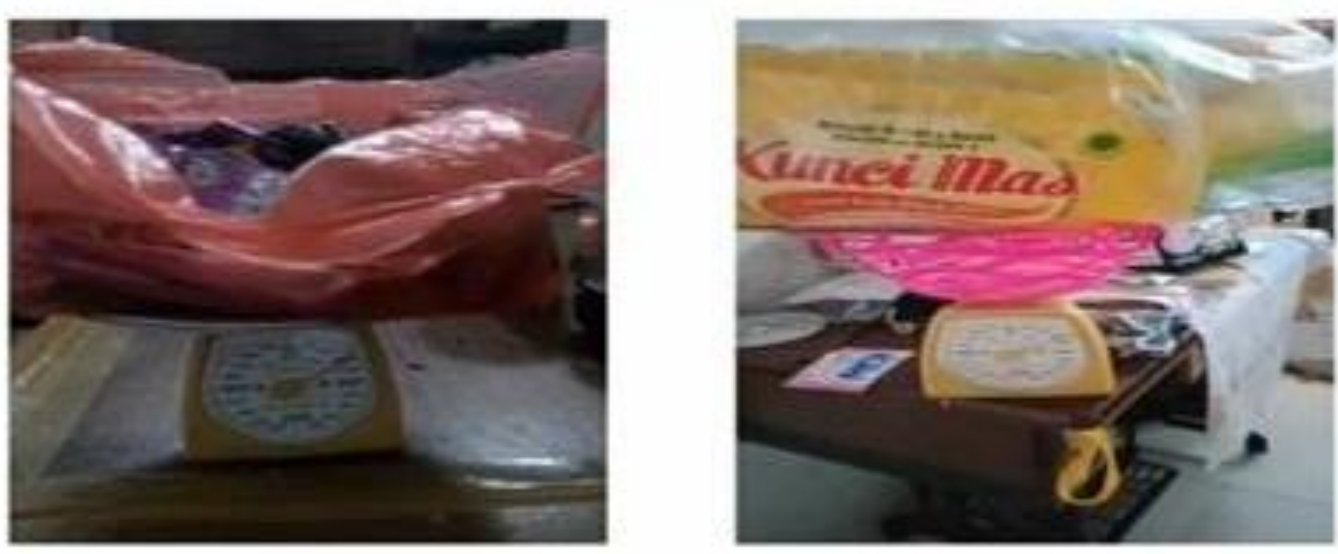

Gambar 2. Penimbangan Sampah untuk Dikonversi Menjadi Point

Perilaku masyarakat tidak serta Ketika aktivitas pengumpulan sampah sudah mulai rutin, namun ibu-ibu yang tertarik hanya 1-2 orang saja, itu pun tidak sampai tuntas membuat kerajinannya. Masalah baru muncul yaitu respons masyarakat untuk pengelolaan sampah masih sebatas pengumpulan sampahnya belum terlalu tertarik sampai tahap pengelolaannya, dengan alasan kurang teliti dan lain-lain. Padahal dalam kondisi pandemic covid 19 seperti sekarang ini, kegiatan ibu-ibu untuk membuat kerajinan tangan berbahan sampah kemasan dapat dilakukan di rumah masing-masing secara mandiri.

Pelatihan tentang pengolahan sampah telah dilaksanakan pada tahun 2018 di tingkat kecamatan. Para pesertanya adalah ibu-ibu PKK yang merupakan perwakilan dari setiap kelurahan. Hanya sebagian kecil masyarakat yang tertarik untuk mengimplementasikan hasil pelatihan tersebut, salah satu diantaranya adalah ibu Tri. Ibu Tri sudah mencoba menularkan kemampuannya terhadap ibu-ibu yang lainnya, namun tidak banyak ibu-ibu yang bersungguh-sungguh ingin mengikuti jejaknya. Hal ini karena ibu-ibu belum peduli dan tertarik akan lingkungan jika seseorang itu mau berubah dia harus mempunyai pengetahuan, sikap dan Tindakan. Hal ini senada dengan pendapat (Kurniawati, 2012; Simanjuntak et al., 2016) terdapat tiga domain untuk perubahan perilaku yaitu pengetahuan, sikap dan tindakan. Pengetahuan masyarakat tentang pengelolaan sampah bisa jadi hasilnya sudah baik, akan tapi untuk domain sikap dan tindakannya belum tentu sejalan.

Berdasarkan masalah tersebut maka tim pengabdian masyarakat Fakultas Keperawatan Universitas Sumatera Utara tertarik untuk melaksanakan pengabdian masyarakat dengan tema "Pemberdayaan Ibu Rumah Tangga dalam Mengelola Sampah di Lingkungan II Kelurahan Asam Kumbang Medan". Kegiatan serupa pernah dilaksanakan sebagai bentuk pengabdian masyarakat di Semarang oleh (Rinjani \& Putri, 2016) menyatakan bahwa Dengan adanya pelatihan pengolahan sampah plastik sebagai kerajinan tangan diharapkan tidak hanya dapat meningkatkan kreativitas dan memanfaatkan barang-barang bekas, tetapi juga dapat membuka lapangan pekerjaan bagi masyarakat. (Diana et al., 2018) menyatakan pelatihan adalah bertambahnya ilmu dan keahlian mitra dalam hal pengelolaan dan pemanfaatan sampah plastik serta mampu membuat tas dan dompet dari sampah plastik bekas kemasan detergen, sabun, pewangi pakaian, dan plastik keresek yang bernilai ekonomis. Namun meskipun kegiatannya memilki kemiripan, implementasi di lapangan sangat berbeda, karena didasarkan pada permasalahan yang dialami mitra serta dipengaruhi oleh karakteristik masyarakatnya. 


\section{Materials and Methods}

Berdasarkan paparan di latar belakang maka permasalahan, solusi dan luarannya adalah seperti tergambar pada Tabel 1.

Tabel 1. Masalah Solusi dan Luaran

\begin{tabular}{|c|c|c|c|}
\hline No & Masalah & Solusi & Luaran \\
\hline 1. & $\begin{array}{lr}\text { Pemahaman } & \text { ibu-ibu } \\
\text { tentang } & \text { pengelolaan } \\
\text { sampah } & \text { perlu } \\
\text { ditingkatkan } & \end{array}$ & 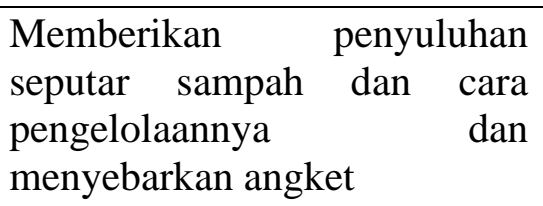 & $\begin{array}{l}\text { Pemahaman ibu-ibu } \\
\text { tentang sampah dan cara } \\
\text { mengelolanya baik. }\end{array}$ \\
\hline 2. & 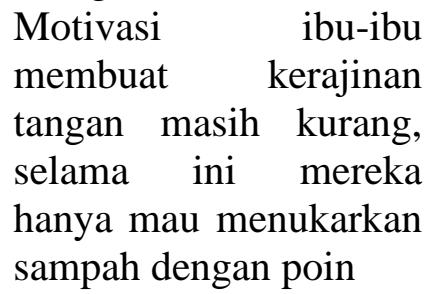 & $\begin{array}{l}\text { Diberikan pelatihan } \\
\text { pembuatan kerajinan tangan } \\
\text { berbahan sampah kemasan dan } \\
\text { setiap ibu-ibu yang dapat } \\
\text { menyelesaikan satu bentuk } \\
\text { kerajinan diberikan hadiah }\end{array}$ & $\begin{array}{l}50 \% \text { ibu-ibu peserta } \\
\text { pelatihan mau } \\
\text { berpartisipasi membuat } \\
\text { kerajinan yang telah } \\
\text { yang diajarkan }\end{array}$ \\
\hline 3 & $\begin{array}{l}\text { Penjualan } \\
\text { kerajinan }\end{array}$ & $\begin{array}{l}\text { Mengorelasikan } \\
\text { kerajinan sesuai dengan } \\
\text { kebutuhan } \\
\text { konsumen dan mermintaan) } \\
\text { jejaring melalui media sosial } \\
\text { untuk memasarkan }\end{array}$ & $\begin{array}{l}50 \% \text { dari karya yang } \\
\text { dihasilkan dapat terjual } \\
\text { di pasaran }\end{array}$ \\
\hline
\end{tabular}

Berdasarkan tiga permasalahan yang telah dipaparkan maka terdapat tiga solusi yang ditawarkan yaitu penyuluhan, pelatihan dan membuat kerajinan sesuai dengan permintaan (kebutuhan) konsumen serta membuat jejaring melalui media sosial untuk pemasaran.

\section{Results and Discussion}

Kegiatan puncak dilaksanakan pada tanggal dilaksanakan pada tanggal 14 Agustus 2020 di aula kantor kelurahan Asam Kumbang, kecamatan Medan Selayang, Kota Medan. Mitra pada kegiatan ini adalah ibu-ibu di lingkungan 2 kelurahan Asam Kumbang, namun untuk pelaksanaan pelatihan diperluas pada tingkat kelurahan dengan harapan akan melahirkan komunitas ibu-ibu di sembilan lingkungan lainnya. Kegiatan diikuti 21 orang ibuibu PKK yang merupakan perwakilan dari 20 lingkungan yang ada di kelurahan Asam Kumbang dan satu ibu ketua PKK kelurahan Asam Kumbang. Berikut adalah rangkaian kegiatan program pengabdian masyarakat Fakultas Keperawatan Universitas Sumatera Utara ini adalah sebagai berikut:

\section{Perencanaan Program}

Perencanaan Program, dimulai dari survey, dilanjutkan dengan koordinasi dan penetuan peserta akan dilibatkan dalam kegiatan pengabdian masyarakat

a. Survei Lapangan, Tujuannya untuk mengamati situasi dan keadaan lingkungan yang direncanakan sebagai objek sasaran, yaitu lingkungan II kelurahan Asam Kumbang Medan.

b. Koordinasi dengan masyarakat dan pemerintah setempat yaitu kepala lingkungan dan lurah Asam Kumbang, kemudian berkoordinasi dengan ibu-ibu PKK setempat untuk kelancaran kegiatan pengabdian masyarakat. 
c. Peserta yang diundang pada kegiatan ini adalah ibu-ibu PKK yang mewakili 10 lingkungan yang berada di kelurahan Asam Kumbang. Setelah mengikuti kegiatan diharapkan para peserta mampu menularkan keterampilan yang dimilikinya kepada ibuibu yang lain.

\section{Pelaksanaan Program}

Kegiatan dilaksanakan di aula kantor kelurahan Asam Kumbang kecamatan Medan Selayang, Kota Medan. Pengabdian masyarakat kali ini dilaksanakan ketika wabah corona virus sedang mengganas, dan hampir semua daerah di kota Medan merupakan zona merah. Oleh karena itu, semua tahapan kegiatan pengabdian masyarakat mengikuti protokol kesehatan yang cukup ketat demi keselamatan bersama, dengan konsep 3M, yaitu mencuci tangan, memakai masker dan menjaga jarak. Konsep 3M tersebut dapat dilihat pada Gambar 3.

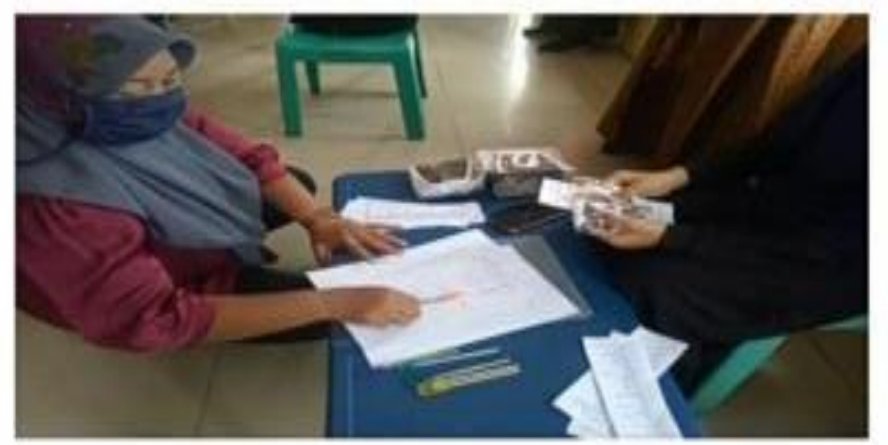

Gambar 3. Pembagian Masker, Angket, dan Pengisian Absen

Adapun rangkaian kegiatannya adalah sebagai berikut: a) Sebelum masuk ruangan aula yang berada di lantai 2, setiap peserta wajib mencuci tangan di tempat yang telah disediakan di lantai 1 di halaman kantor kelurahan; b) Peserta mengganti masker yang dipakai dari rumah, dengan masker yang sudah disediakan tim pengabdian masyarakat dan mengisi absen yang sudah disiapkan; c) Kata sambutan dari ketua tim pengabdian masyarakat; d) Sambutan dari lurah Asam Kumbang sekaligus membuka acara kegiatan; e) Pembacaan doa sebelum acara inti; f) Penyegaran materi seputar sampah dan cara mengelolanya; g) Peserta diberikan angket tentang sampah dan pengelolaannya, untuk diisi dan dikumpulkan kembali kepada tim pengabdian masyarakat; h) Sosialisasi dan Pelatihan atau praktik langsung pembuatan kerajinan tangan yang dipandu oleh tim pengabdian masyarakat; i) Foto bersama dan Penutup. Rangkaian kegiatan tersebut dapat dilihat pada Gambar 4, Gambar 5, Gambar 6, Gambar 7 Gambar 8, Gambar 9, Gambar 10, dan Gambar 11. 


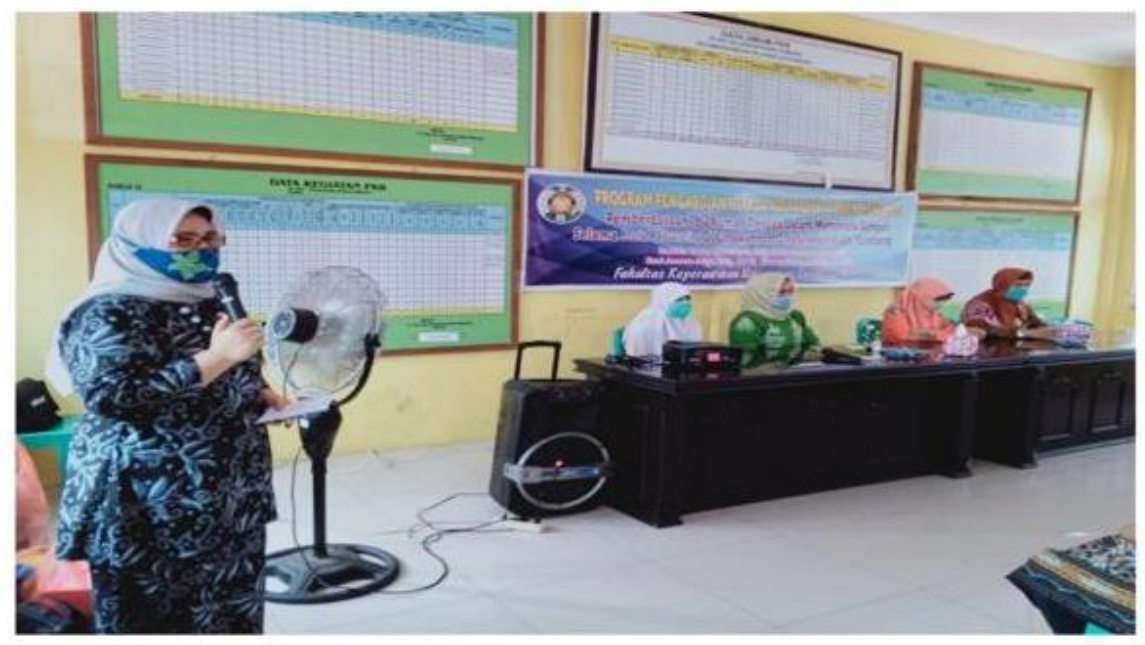

Gambar 4. Pembukaan Kegiatan Pengabdian Masyarakat

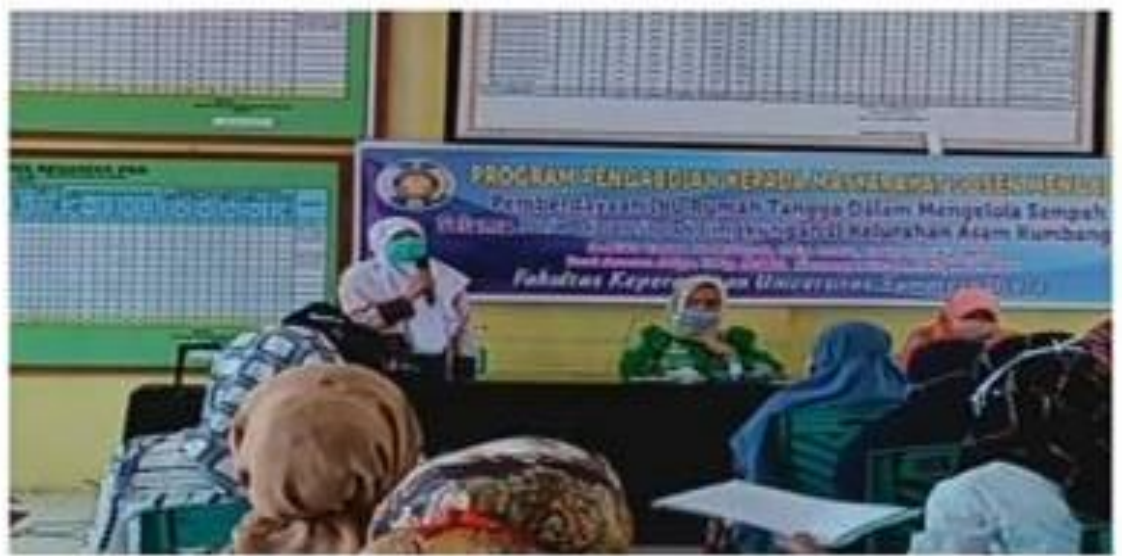

Gambar 5. Pembukaan oleh Ketua Tim Pelaksana Pengabdian Masyarakat

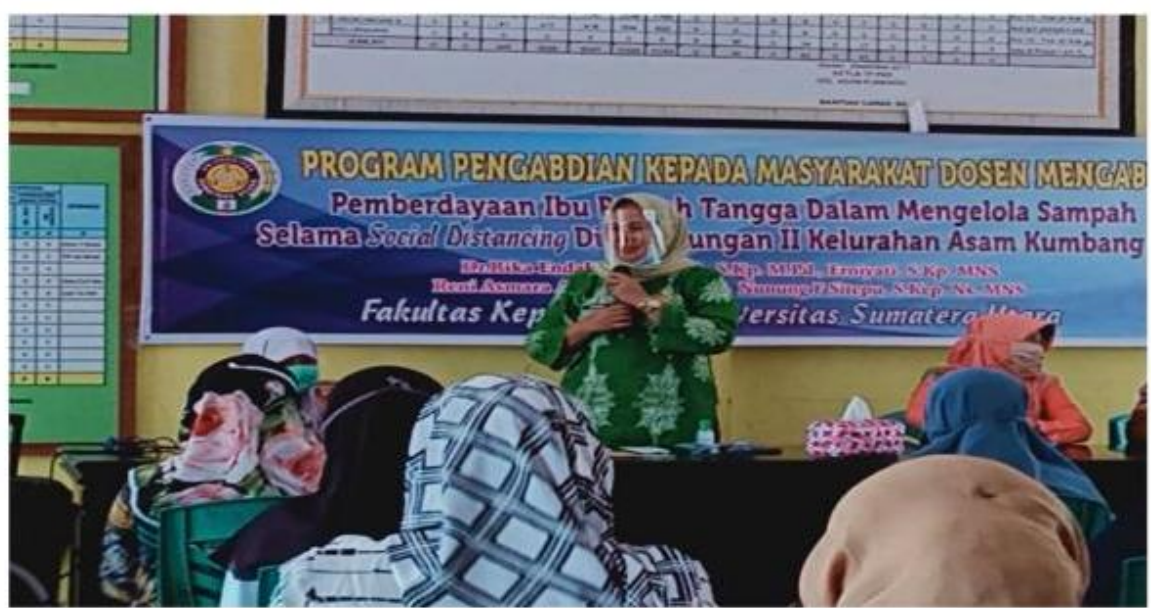

Gambar 6. Pembukaan oleh Lurah Asam Kumbang Medan 


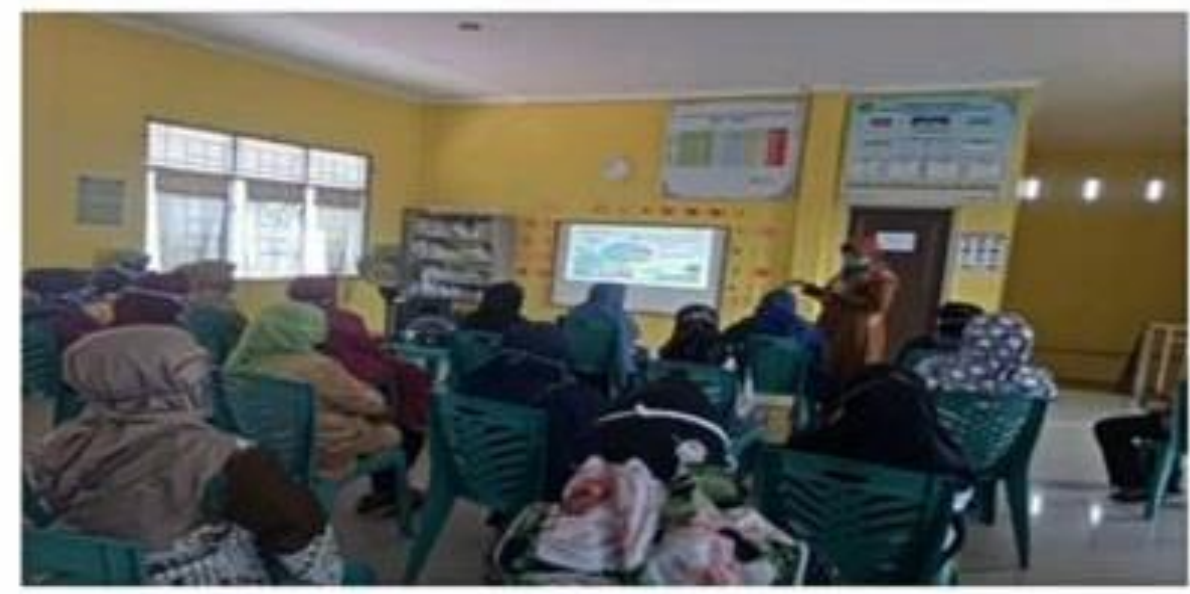

Gambar 7. Penyegaran Materi Seputar Sampah dan Pengelolaannya

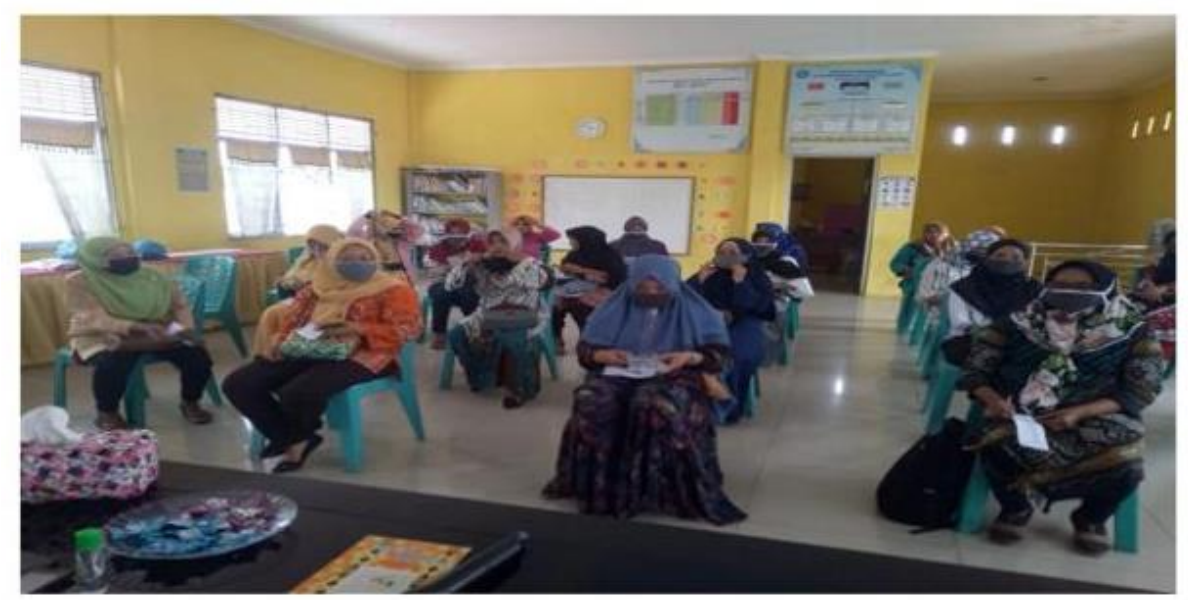

Gambar 8. Pengisian Angket oleh Peserta

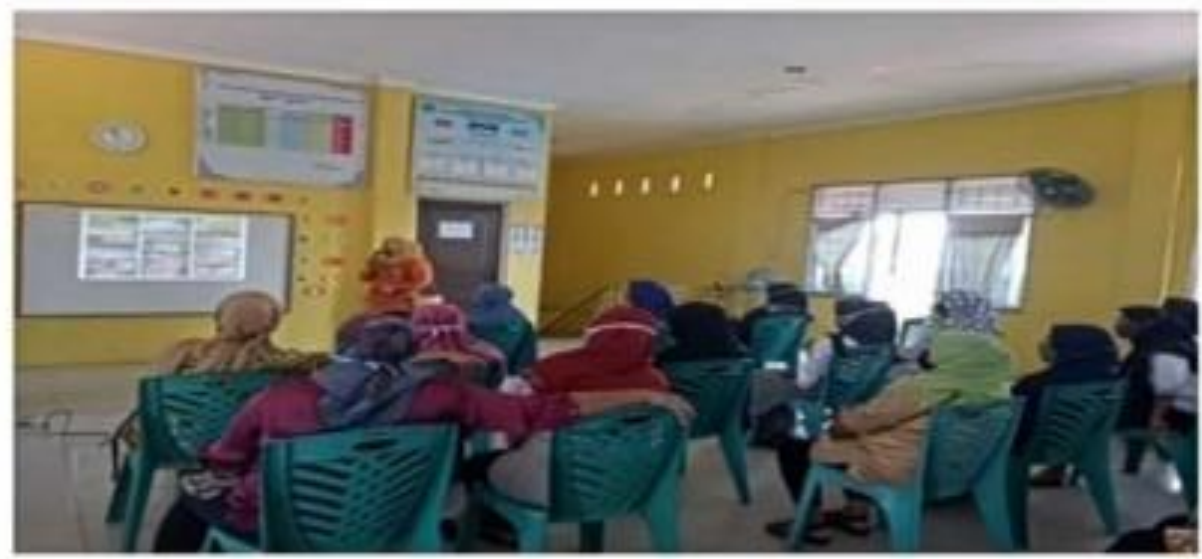

Gambar 9. Pemberian Materi Tentang Pembuatan Kerajinan Tangan dari Sampah 


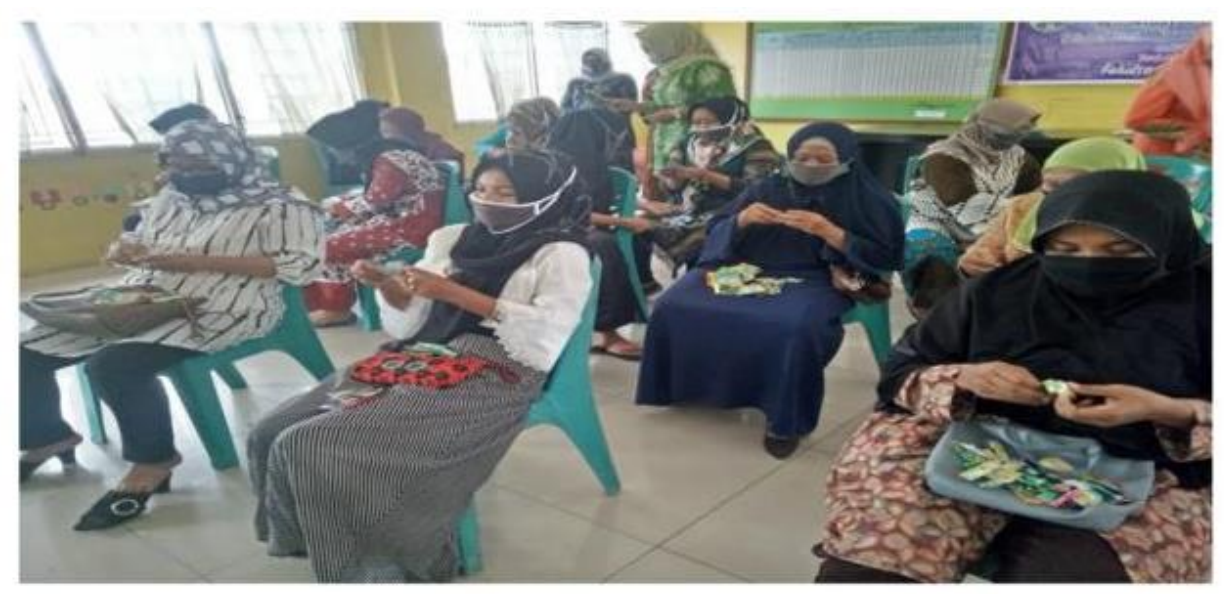

Gambar 10. Pelaksanaan Pembuatan Kerajinan Tangan dengan Tetap Memperhatikan Protokol Kesehatan

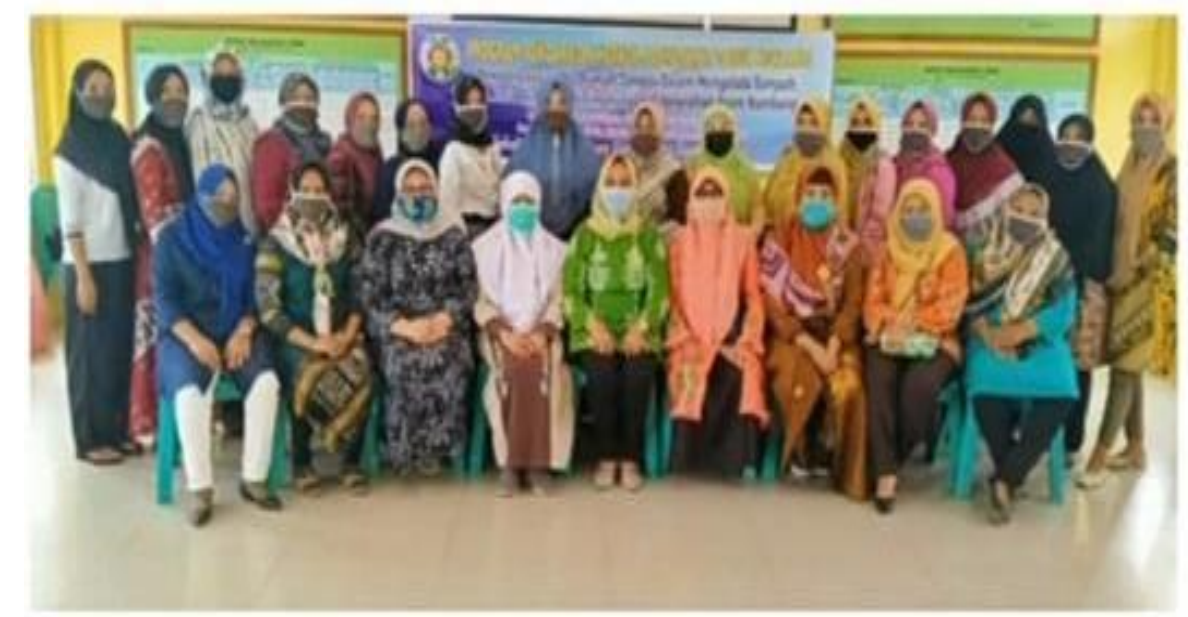

Gambar 11. Foto Bersama Tim Pengabdian Masyarakat, Lurah, dan Peserta

\section{Evaluasi Program}

Evaluasi perkembangan pelaksanaan program pengabdian masyarakat dilakukan selama kurang lebih satu bulan setelah kegiatan berlangsung. Khususnya untuk perilaku masyarakat dalam pembuatan kerajinan. Sebagaimana harapan di awal bahwa ibu-ibu bukan saja tertarik untuk mengumpulkan sampah yang akan ditukar dengan sembako tetapi juga ikut berperan aktif dalam pembuatan kerajinan tangan, bahkan sampai ikut membantu membuat jejaring untuk pemasaran kerajinan tangan yang dihasilkan. Hasil evaluasi seperti tertera pada Tabel 2 berikut ini dan hasil harya dapat dilihat pada Gambar 12.

Tabel 2. Evaluasi dan Keberlanjutan

\begin{tabular}{|c|c|c|c|}
\hline No & Solusi & Evaluasi & Keberlanjutan \\
\hline 1 & \begin{tabular}{lrr} 
Memberikan & \multicolumn{2}{c}{ penyuluhan } \\
seputar sampah dan cara \\
pengelolaannya & & dan \\
menyebarkan angket & &
\end{tabular} & $\begin{array}{l}\text { Evaluasi pemahaman } \\
\text { peserta dari angket yang } \\
\text { diberikan }\end{array}$ & $\begin{array}{l}\text { Pemahaman peserta } \\
\text { sudah baik, dengan } \\
\text { rerata hasil tes di atas } \\
80 \%\end{array}$ \\
\hline
\end{tabular}




\begin{tabular}{|c|c|c|c|}
\hline No & Solusi & Evaluasi & Keberlanjutan \\
\hline 2 & $\begin{array}{l}\text { Diberikan pelatihan pembuatan } \\
\text { kerajinan tangan berbahan } \\
\text { sampah kemasan dan setiap } \\
\text { ibu-ibu yang dapat } \\
\text { menyelesaikan satu bentuk } \\
\text { kerajinan diberikan hadiah }\end{array}$ & $\begin{array}{l}\text { Saat pelatihan peserta } \\
\text { cukup antusias mengikuti } \\
\text { kegiatan, tetapi yang mau } \\
\text { menyelesai-kan kerajinan } \\
\text { sampai tuntas hanya } 3 \\
\text { orang }(14,3 \%)\end{array}$ & $\begin{array}{l}\text { Tetap dibutuhkan } \\
\text { pendampingan dan } \\
\text { pertemuan yang rutin } \\
\text { agar ibu-ibu tetap } \\
\text { termotivasi }\end{array}$ \\
\hline 3 & $\begin{array}{l}\text { Mengkreasikan model } \\
\text { kerajinan sesuai dengan } \\
\text { kebutuhan (permintaan) } \\
\text { masyarakat dan membuat } \\
\text { jejaring melalui media sosial } \\
\text { untuk memasarkan }\end{array}$ & $\begin{array}{l}\text { Karya yang dihasilkan } \\
\text { mulai beragam, tetapi } \\
\text { kendalanya belum banyak } \\
\text { ibu-ibu mau berperan } \\
\text { aktif dalam pembuatan } \\
\text { kerajinan apalagi ikut } \\
\text { memasarkan }\end{array}$ & $\begin{array}{l}\text { Butuh pendampingan } \\
\text { kepada mitra agar } \\
\text { tetap mau berkarya, } \\
\text { dan membutuhkan } \\
\text { waktu kesabaran } \\
\text { dalam pembinaan } \\
\text { dengan waktu yang } \\
\text { juga tidak sebentar. }\end{array}$ \\
\hline
\end{tabular}
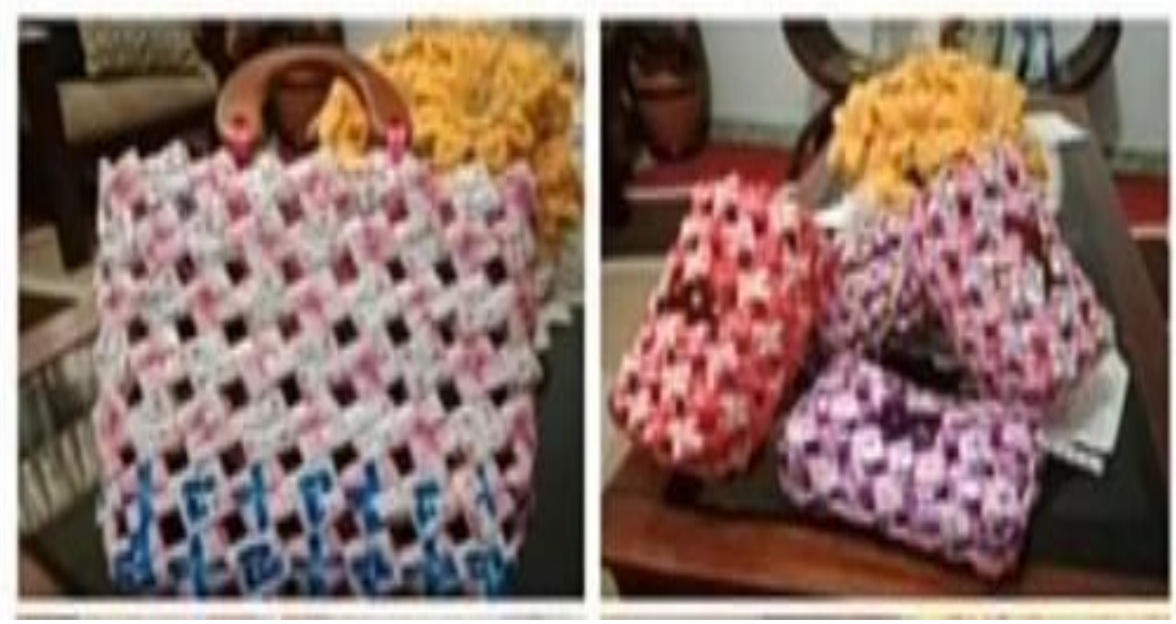

Gambar 12. Contoh Hasil Karya Yang Siap Dipasarkan

Berdasarkan hasil evaluasi, kegiatan pengabdian masyarakat secara keseluruhan berjalan lancar. Ibu-ibu peserta pelatihan atau pemberdayaan cukup antusias. Hasil penyebaran angket menunjukkan bahwa rerata pengetahuan ibu-ibu tentang sampah dan pengelolaannya sudah sangat memadai (baik) akan tetapi untuk domain sikap dan tindakan menunjukkan bahwa ibu-ibu masih membutuhkan motivasi, pembinaan dan pendampingan khusus agar tetap mau berkarya. Persepsi masyarakat terhadap sosialisasi program pengelolaan sampah secara 3R (Reduce, Reuse, Recycle) masih tergolong netral, hal ini disebabkan masih kurangnya sosialisasi yang dilakukan pemerintah terhadap masyarakat (Ali \& Christiawan, 2019; Malee et al., 2016). Sikap sebagai respons tertutup seseorang terhadap stimulus atau objek tertentu, yang sudah melibatkan faktor pendapat dan emosi (Retnaningsih, 2016). Berdasarkan pendapat tersebut, maka dapat dikatakan bahwa banyak faktor yang mempengaruhi seseorang untuk bersikap atau pun melakukan sebuah tindakan. Pendapat orang lain, kemudian mindset yang juga terbentuk sendiri dalam pikirannya dapat mempengaruhi keinginannya untuk bersikap dan bertindak. Oleh karena itu diperlukan pemberian motivasi yang baik dan terus menerus untuk merubah mindsetnya.

Dengan memberikan pelatihan, pendampingan dan bimbingan akan membuat masyarakat lebih termotivasi untuk menyelesaikan apa yang mereka kerjakan. Karena pelatihan akan bermanfaaat menambah pengetahuan dan ketrampilan masyarakat tentang 
pemanfaatan barang bekas untuk pembuatan barang kerajinan sebagai produk yang bernilai jual (Astuti et al., 2019). Akan tetapi, hanya pelaithan dan pendampingan tidaklah cukup untuk membatu masyarakat, adanya perubahan pola pikir mayarakat pengguna barang juga harus diubah agar tidak percuma ada banyak produksi barang kerejainan tapi minat untuk membeli tidaklah ada.

Kegiatan pengabdian masyarakat secara keseluruhan berjalan lancar dengan antusiasme dari para peserta selama mengikuti kegiatan. Hasil evaluasi untuk pengetahuan pada dasarnya sudah sangat memadai (baik) akan tetapi untuk domain sikap dan tindakan menunjukkan bahwa ibu-ibu masih membutuhkan motivasi, pembinaan dan pendampingan khusus agar tetap mau berkarya.

\section{Conclusion}

Kegiatan pengabdian masyarakat secara keseluruhan berjalan lancar dengan antusiasme dari para peserta selama mengikuti kegiatan. Hasil evaluasi untuk pengetahuan pada dasarnya sudah sangat memadai (baik) akan tetapi untuk domain sikap dan tindakan menunjukkan bahwa ibu-ibu masih membutuhkan motivasi, pembinaan dan pendampingan khusus agar tetap mau berkarya. Stigma masyarakat yang memandang kerajinan dari barang bekas kurang bernilai turut mempengaruhi motivasi ibu-ibu dalam menyelesaikan kerajinan tangan, oleh karena itu pendampingan dan pembinaan yang terus menurus perlu dilakukan agar kegiatan ini tetap berkesinambungan.

\section{References}

Ali, M., \& Christiawan, P. I. (2019). Tingkat Partisipasi Pedagang Dalam Pengelolaan Sampah Pasar Tradisional Di Kota Singaraja. Jurnal Pendidikan Geografi Undiksha, 7(1), 1-7. https://doi.org/10.23887/jjpg.v7i1.20672

Astuti, I. P., Buntoro, G. A., \& Ariyadi, D. (2019). Pelatihan Pemanfaatan Barang Bekas Untuk Pembuatan Buket Bunga Dan Cara Pemasarannya. Warta LPM, 21(2), 6-10. https://doi.org/10.23917/warta.v21i2.7739

Chaerul, M., \& Rahayu, S. A. (2019). Cost Benefit Analysis dalam Pengembangan Fasilitas Pengolahan Sampah: Studi Kasus Kota Pekanbaru. Jurnal Pengelolaan Sumberdaya Alam Dan Lingkungan (Journal of Natural Resources and Environmental Management), 9(3), 710-722. https://doi.org/10.29244/jps1.9.3.710-722

Dewi, N. A. K., Pratiwi, R., \& Muzayyanah, L. (2020). Pelatihan Keterampilan Kain Perca untuk Mengurangi Limbah Anorganik. Sasambo: Jurnal Abdimas (Journal of Community Service), 2(2), 49. https://doi.org/10.36312/sasambo.v2i2.196

Diana, S., Marlina, M., Amalia, Z., \& Amalia, A. (2018). Pemanfaatan Sampah Plastik Menjadi Produk Kerajinan Tangan Bernilai Ekonomis Bagi Remaja Putus Sekolah. Jurnal Vokasi - Politeknik Negeri Lhokseumawe, 1(1), 68-73. https://doi.org/10.30811/vokasi.v1i1.570

Harahap, R. D. (2016). Pengaruh Sampah Rumah Tangga Terhadap Pelestarian Lingkungan Ditinjau Dari Aspek Biologi Di Komplek Perumahan Graha Pertiwi Kel. Urung Kompas Kec. Rantau Selatan Effect of Household Waste Viewed From the Aspect Environmental Conservation Biology in Housing Complex Graha Pertiwi Kel. Undo Kompas Kec. South Rantau. Cahaya Pendidikan, 2(1), 92-104. https://doi.org/10.33373/chypend.v2i1.609

Kahfi, A. (2017). Tinjauan Terhadap Pengelolaan Sampah. Jurisprudentie: Jurusan Ilmu Hukum Fakultas Syariah Dan Hukum, 4(1), 12. 
https://doi.org/10.24252/jurisprudentie.v4i1.3661

Kurniawati, D. (2012). Implementasi Pendidikan Kesehatan sebgai Sebuah Upaya untuk Meningkatkan Pengetahuan dan Perilaku Ibu dalam Memberikan ASI eksklusif. Pengembangan Pendidikan, 9(2), 432-442. https://media.neliti.com/media/publications/210292-implementasipendidikankesehatan-sebagai.pdf

Malee, M. R., L.S, B. O., \& Wangke, W. M. (2016). Persepsi Masyarakat , Pengelolaan Sampah , Manembo-nembo Tengah, Kota Bitung. Agri-Sosioekonomi, 12(Juli 2016), 225-238. https://ejournal.unsrat.ac.id/index.php/jisep/article/view/12877

Marliani, N. (2015). Pemanfaatan Limbah Rumah Tangga (Sampah Anorganik) Sebagai Bentuk Implementasi dari Pendidikan Lingkungan Hidup. Formatif: Jurnal Ilmiah Pendidikan MIPA, 4(2), 124-132. https://doi.org/10.30998/formatif.v4i2.146

Nadlifatin, R. (2018). Processing of Plastic Waste into Handicraft Products to Improve the Economy of the Sendang Dajah Community. Jurnal Abdikarya: Jurnal Karya Pengabdian Dosen Dan Mahasiswa, 1(1), 98-102. http://jurnal.untagsby.ac.id/index.php/abdikarya/article/viewFile/3746/2850

Naryono, E. S. (2011). Pemanfaatan Residu Pembakaran Sampah Organik Rumah Tangga. JPAL, 2(1), 1-9. https://jpal.ub.ac.id/index.php/jpal/article/view/128

Qorira, A. A., \& Waskito, A. (2020). Eksplorasi Material Pvc Lembaran Dari Sampah Sisa Bahan. Jurnal Desain Indonesai, 02(1), 11-16. https://jurnal-desainindonesia.com/index.php/jdi/article/view/36

Retnaningsih, R. (2016). Hubungan Pengetahuan Dan Sikap Tentang Alat Pelindung Telinga Dengan Penggunaannya Pada Pekerja Di Pt. X. Journal of Industrial Hygiene and Occupational Health, 1(1), 67. https://doi.org/10.21111/jihoh.v1i1.607

Rinjani, E. D., \& Putri, L. I. (2016). Pemberdayaan Kelompok Pkk Dalam Pengolahan Sampah Plastik Menjadi Produk Kerajinan Tangan. Abdimas Unwahas, 1(1), 28-33.

Simanjuntak, R. D., Solichin, S., \& Fanani, E. (2016). Pengaruh Penyuluhan Terhadap Peningkatan Perilaku Penggunaan Alat Pelindung Diri. Preventia: The Indonesian Journal of Public Health, 1(2), 174. https://doi.org/10.17977/um044v1i2p174-185

Wardhani, M. K., \& Harto, A. D. (2018). Studi Komparasi Pengurangan Timbulan Sampah Berbasis Masyarakat Menggunakan Prinsip Bank Sampah di Surabaya, Gresik dan Sidoarjo. Jurnal PAMATOR, 11(1), 52-63. http://journal.trunojoyo.ac.id/pamator

Yudistira, H. (2019). Pola Perilaku Membuang Sampah Masyarakat Kampung Sangir Kelurahan Titiwungen Selatan Di Daerah Aliran Sungai Sario. Journal of Chemical Information and Modeling, 53(9), 1689-1699.

Yustikarini, R., Setyono, P., \& Wiryanto. (2017). Evaluasi dan Kajian Penanganan Sampah dalam Mengurangi Beban Tempat Pemrosesan Akhir Sampah di TPA Milangasri Kabupaten Magetan. Journal of Biology Education Conference, 14, 177-185. https://jurnal.uns.ac.id/prosbi/article/download/17642/14068 